Journal of

Women's Health and Gynecology

\title{
Chronic Pain Syndrome of Women
}

\section{Mary Smith}

MedStar Georgetown University Hospital, Washington, DC 20007, USA

*Corresponding author: Mary Smith, MedStar Georgetown University Hospital, Washington, DC 20007, USA, Tel: +248-6024067, E-mail: ms0077693@gmail.com

Received Date: May 18, 2019 Accepted Date: May 20, 2019 Published Date: May 22, 2019

Citation: Mary Smith (2019) Chronic Pain Syndrome of Women. J Womens Health Gyn 6: 1-6.

\begin{abstract}
This group of patients are usually diagnosed with the Fibromyalgia, Arthritis, Hypochondria, Anxiety- depressive disorder, and chronic fatigue syndrome. In this group of patients, a long history of respiratory diseases like chronic sinusitis, chronic otitis, turbinate hypertrophy, nasal congestion, chronic rhinitis (Figure.1). chronic pain picture in women's population presented with Pelvic pain, musculoskeletal pain, lumbar pain, back pain, polyarticular pain, and malaise.
\end{abstract}

\section{Materials and Methods}

One hundred female patients in Juan de D-s Hospital at ages 20 to 60 years old with symptomatology, we have found history of the consultation for other causes different type of pain. Most of the other consultations are related with the respiratory infections.

\section{Findings on physical examination}

- $\quad$ Chronic sinusitis $70 \%$

- Chronic tonsillitis $40 \%$

- Chronic otitis $20 \%$

- $\quad$ Turbinate hypertrophy $20 \%$

- $\quad$ Nasal congestion $20 \%$

- Chronic rhinitis $45 \%$

- Musculoskeletal Tenderness on palpation: $100 \%$ Tenderness on renal fossae palpation 90\% Tenderness on bimanual pelvic palpation $90 \%$.

(c)2019 The Authors. Published by the JScholar under the terms of the Creative Commons Attribution License http://creativecommons.org/licenses/ by/3.0/, which permits unrestricted use, provided the original author and source are credited. 


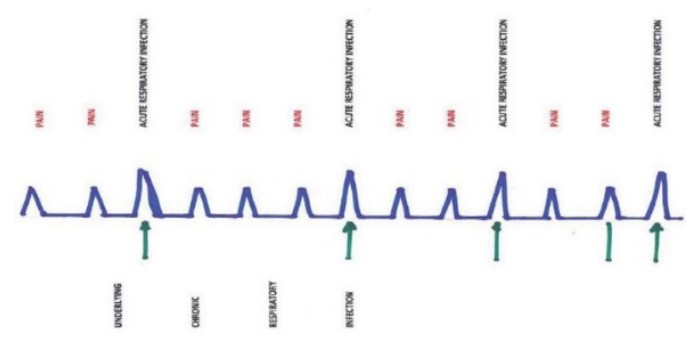

Figure 1: Clinical history with underlying chronic respiratory infection.

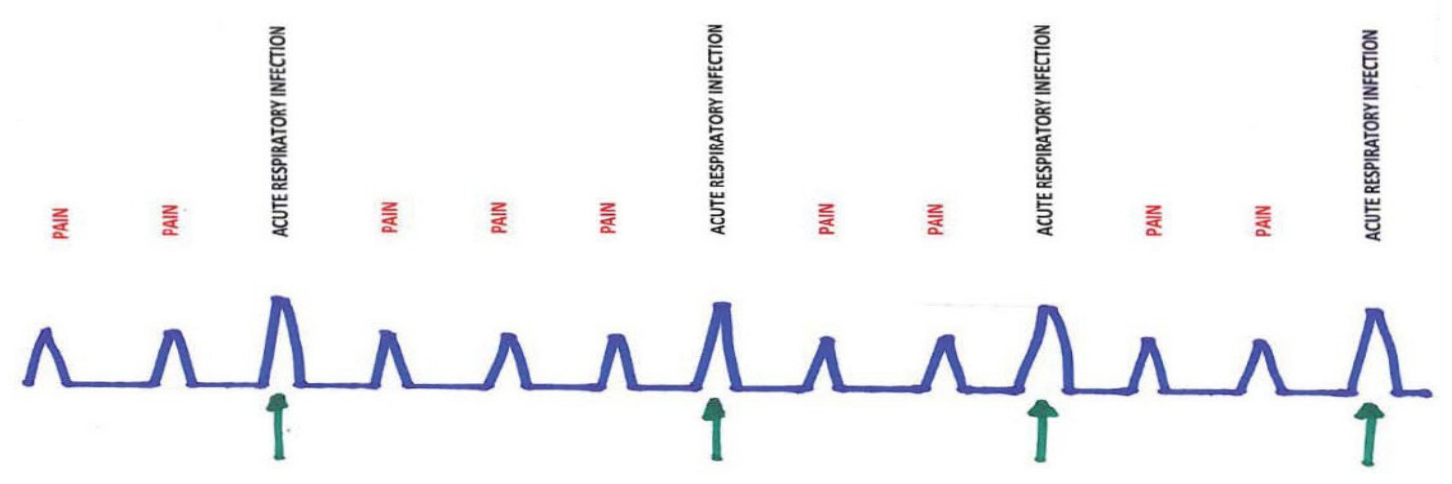

Figure 2: Diagram of the clinical history

According to these findings the anamnesis on physical examination, we suppose the acute respiratory episodes are manifestations of underlying CR infection (Figure.2). 
What Is the Relationship Between the Pain Picture Described in This Group of Patients, The Chronic Respiratory Infection?

The presence of an acute infectious process causes the immune system to catch the infection (antigen) by antibodies ( $\mathrm{IgM}$, IgD, and $\operatorname{IgG}$ ). Antigens bound to antibodies in immune complexes through an acute infectious process are normally cleared by various cellular mechanisms (reticuloendothelial system). But when we have a chronic infection, we have a reticuloendothelial system and an overload of immune complexes. Immune complexes deposit on different tissues: joint structures, musculoskeletal system, endothelium of small vessels.

Immune disorders develop immune complexes deposit pathologically in the different organs, initiating to inflammatory arcades which led to organ damaged/disease. Immune complexes are deposited on articular surfaces, musculoskeletal system, renal glomerular basement membranes and vascular basement membranes and produce immune mediated inflammation, activation of humoral or cellular effectors mechanisms, activation of complement, release of chemotactic factors, neutrophil accumulation, release of lysosomal enzymes, inflammation of vascular basement membranes, inflammation of joint surfaces, inflammation of the musculoskeletal system, inflammation of renal glomerular basement membrane, inflammation of pelvic structures, tissue remodeling.

What we have in this group of patients are chronic inflammation which are have named: WOMEN'S CHRONIC PAIN SYNDROME. The disease with a clear picture of signs and symptoms. A disease with a clear pathophysiology: Immune complexes disease. A disease with clear target organs: joints, kidney, musculoskeletal system, basal membranes of small vessels. This is immune complexes disease described from clinical observation.

\section{References}

1. Harrison, Principles of the Internal Medicine, Inc. 451. 1977.

2. Merck Manual, Immunology and Allergy, chap. 2., ninth edition 1994.

3. Roitt, Ivan. Immunology Foundation, seventh edition 1994, Medica Panamericana, chap. 6., chap. 7

Submit your manuscript to a JScholar journal and benefit from:

ๆ Convenient online submission

ब Rigorous peer review

q Immediate publication on acceptance

q Open access: articles freely available online

I High visibility within the field

I Better discount for your subsequent articles

Submit your manuscript at http://www.jscholaronline.org/submit-manuscript.php 